\title{
AN INSIGHT INTO BUSINESS ADMINISTRATION GRADUATES' ENGLISH ORAL COMMUNICATION COMPETENCIES FROM WORKPLACE PERSPECTIVES
}

\author{
Nguyen Thi Minh Tram* \\ Honors Program, Faculty of English Language Teacher Education, \\ VNU University of Languages and International Studies, \\ Pham Van Dong, Cau Giay, Hanoi, Vietnam \\ Received 13 November 2019 \\ Revised 15 December 2019; Accepted 11 February 2020.
}

\begin{abstract}
The issue of discrepancies between university English business administration curriculum and English oral communication competence requirements in the workplace has been increasingly alarming since Vietnam accessed into more and more international business organizations, especially ASEAN Economic Community. In the present study, qualitative data were collected in semi-structured interviews with stakeholders in real workplace, consisting of 15 employers at executive and managerial level and 8 business administration graduates from four universities to explore this mismatch. The results showed that most of the employers and graduates were slightly dissatisfied or dissatisfied with business administration graduates' English oral communication competencies in workplace right after their graduation. Specifically, most of the business administration graduates lacked good pronunciation, skills and appropriate attitudes rather than knowledge in dealing with English oral communication tasks. Importantly, much of the dissatisfaction of both employers and graduates came from the discrepancies between the university preparation and workplace requirements. Thus, creating long-term collaborative partnerships among and between academic institutes and potential employers and designing a competency-based course are essential in preparing business administration undergraduates efficiently for the increasingly demanding workplace regarding English oral communication competencies.
\end{abstract}

Keywords: oral communication in English, business administration, competency

\section{1. introduction}

In the overall strategy for international integration through 2020, vision to 2030 approved by the Vietnamese Prime Minister in 2016 (Decision No. 40 dated January 7), the importance of foreign languages and especially English for the labor force was emphasized to meet the demands of the integration process. Therefore, Vietnamese learners who major in business administration (BA) require effective English oral communication (EOC) competencies in this area if they want to be

\footnotetext{
* Tel.: 84-91537 1945
}

Email: tramntm@vnu.edu.vn/minhtramsv@yahoo.com successful in the increasingly dynamic and demanding job market.

On the one hand, although adequate English competencies are usually among the first requirements for job applicants in business, Hoang's (2008) research reveals that $50 \%$ of non-English major student participants $(\mathrm{N}=60)$ could not communicate in English in simple situations. Do (2012) has also found that $90 \%$ of Vietnamese third year non- English major students $(\mathrm{N}=9900)$ fell well below employers' requirements related to the Test of English for International Communication. On the other hand, many recent studies in Asia 
(e.g., Dayal, 2005; Vasavakul \& Chinokul, 2006; Chien, Lee \& Kao, 2008; Tsou, 2009; Pattanapichet \& Chinokul, 2009; Dibakanaka \& Hiranburana, 2012) show the necessity and effectiveness of ESP courses offered in universities which have a focus that is relevant and supplemental to professions related to the students' program major to develop their competencies. However, there is not much information about the workplace investigation of EOC competencies for BA major.

These practical reasons have stressed the necessity of an investigation into the workplace perspectives so that BA undergraduates' EOC competencies can be developed to receive more opportunities in job employment and meet the language requirements of the demanding workplace right after graduation. Hence, the research question that the present study sought to answer is as follows: How satisfactory are BA graduates' EOC competencies in their workplace?

\section{Competency}

Hymes (1972) has originally formulated the concept of communicative competence that involves judgments about what is systemically possible (what the grammar will allow), psychologically feasible (what the mind will allow), and socioculturally appropriate (what society will allow), and about the probability of occurrence of a linguistic event and what is entailed in the actual accomplishment of it. Richard and Rodgers (2001) assert that competencies as "a description of the essential skills, knowledge and attitude required for effective performance of particular tasks and activities" (p.159). Council of Europe (2001) also shares this idea when defining competencies as "sum of knowledge, skills and characteristics that allow a person to perform action" (p.9). Thus, the structure of competency is formed by experience that includes knowledge, skills and attitudes, which determine an individual's readiness for activity.

Regarding competency-based education, it emerged in the 1970s in the US and referred to an educational movement that advocated defining educational goals in terms of precise measurable description of the knowledge, skills, and behaviours students should acquire at the end of a course of study (Guskey, 2005). The application of competency-based education principles to language teaching is called competency-based language teaching - an approach that has been widely used as the basis for the design of work-related and survival-oriented language teaching programs for adults (Richards, 2006).

\section{Business English oral communication}

With regard to the core areas of oral communication, Savignon (1983) gives specific categories of oral communication abilities which include (1) linguistic competence with five components namely appropriateness, grammatical accuracy, intelligibility, fluency, and the adequacy of vocabulary for purpose, (2) discourse competence consisting of cohesion markers and proper length of pause less than three seconds, (3) strategic competence that demonstrates how the speaker react to others' silence and how they fix their own silence, and (4) nonverbal features of communicative competence that include the ability to display eye contact, smile, and keeping appropriate conversational distance between 60 to 90 centimeters in face-to-face communication. On the other hand, Ellis and Johnson (1994) have provided a more general description that oral communication includes the abilities such as interacting successfully with other speakers, responding appropriately and using the appropriate vocabulary and phrases for the situation they are in and the person they are talking to, for example the 
appropriate language in a job interview or taking a telephone message. Therefore, appropriateness is considered the key in all the aspects of communication, from verbal to non-verbal language.

The communicative language competences by Common European Framework of Reference for Languages (CEF) (Council of Europe, 2001) cover all the components mentioned by the above authors with linguistic, sociolinguistic and pragmatic competences. Specifically, regarding Business English oral communication(BEOC), Crosling and Ward (2002) have said that it covers a wide area, ranging from oral presentations to participation in teams and meetings and, for university courses to be focused appropriately, more detailed information on the spoken interactions. However, DudleyEvans and John (1996, p.26) provide a more comprehensive summary of BEOC with core performance areas in published materials. They (1996) have noted that the BEOC is defined primarily in relation to five core performance areas including taking part in meetings, giving presentations, telephoning, socializing and negotiating.

\section{Research methodology}

The present study adopts a qualitative design. The qualitative data from semistructured interviews can be a rich source to explore and specify the participants' perspectives.

\section{Participants and sampling}

To serve the purpose of the study, two groups of participants were recruited, namely BA graduates and their employers to provide an insightful report of the BA graduates' EOC competencies in their workplace. According to Long (2005), comparing data from different sources can help validate the data and ultimately increase credibility of the interpretation of the data. Semi-structured interviews were conducted in a NA in which the participants were selected based on purposive sampling and they were required to satisfy a number of criteria. As a result of the sampling process, 23 participants consisting of 8 BA graduates from four universities (A, $\mathrm{B}, \mathrm{C}$ and $\mathrm{D})$ that trained $\mathrm{BA}$ undergraduates in Hanoi, and 15 employers were selectively chosen to ensure cross-data validity.

Specifically, BA graduates who experienced both learning needs and communication needs could give in-depth report on the possible discrepancies between the academic preparation and real workplace. They included those who have graduated from the universities and were required to have minimum of one year working in business sectors and speak English on regular basis in their workplace. As a result of the sampling process, eight graduates who used EOC on regular basis were selected: four were sales personnel; two were manager assistants and two were sales administrators in the field of commerce, travel, and manufacturing where they had frequent chances of using EOC (See Appendix 1).

Selected employers who could provide rich information about the requirements of target workplace needed to be at executive and managerial level with over 10 years of working experience, and have some experience recruiting and employing $\mathrm{BA}$ entry-level personnel who had to use EOC in business situations for their job on regular basis. As a result of the sampling process, 15 chosen employers worked in different kinds of organizations where their employees had frequent chances of using EOC and in the same fields with the selected BA graduates. Importantly, all of them had BA graduates as employees for one year and above. Those employers' organizations were located in the major provinces and cities with large 
industrial zones, groups, and companies in Northern Vietnam (See Appendix 2).

\section{Data collection instrument}

Semi-structured interview based on the document analysis to collect qualitative data from graduates and employers was conducted. As Dowsett (1986) outlines the strengths of this instrument, "the interactions are incredibly rich and the data indicate that you can produce extraordinary evidence about life that you do not get in structured interviews or questionnaire methodology" (p. 53).

Regarding the development process of the interview, prior to the administration of the interviews, the questions were consulted by two experts in research and piloted on two practitioner instructors so as to see whether the interview questions were understandable, clear and easy to answer. Then some adaptations related to the wording of the questions were done.

Concerning its design, semi-structured interview forms including a set of openended questions were designed in Vietnamese for graduates and employers. The common question contents were mainly about the common positions of new BA graduates, the satisfaction towards BA graduates' EOC competencies, their difficulties in using EOC in the workplace and suggestions for important EOC performance areas for new BA graduates.

\section{Data collection procedure}

Time, place and mode of each interview were negotiated with each interviewee. The interviews were either face-to-face or through telephone calls (See Appendix 1 \& 2). Contacting through telephone resulted from the fact those participants had busy working schedules. Furthermore, they resided in different provinces so phone calls were favorable options in some of the interviews. In spite of different ways of contacting, the language used was spoken Vietnamese, and the time was chosen upon the participants' convenience and agreed by the researcher, which was in an attempt to ensure the quality of interviews through phone calls as good as face-to-face ones.

The time for each interview employers and graduates varied between approximately 13 and 27 minutes, all added up to around 6 hour 47 minutes (See Appendix $1 \& 2$ ). Before each interview, the participants were sent the guiding interview questions so that they could have more time to think and then possibly give valid answers later in the interviews. All the interviews were conducted in Vietnamese so that interviewees can express themselves freely without language boundaries because not all employers can speak English fluently. The interviews were also audio-taped with the participants' permission for later analysis. During each interview, the researcher also took a note of the main ideas of the answers.

\section{Data analysis procedure}

Qualitative data analysis approach termed "interactive synthesis" (Huberman \& Miles, 1994) was used in the study. This approach combined both case-oriented and variable oriented strategies. Starting with a variableoriented strategy of "finding themes that cut across cases" (Huberman \& Miles, 1994) to compose a "general condensation" (Fischer $\&$ Wertz, 1975) of the data, the study then returned to individual cases for configuration within each case, and performed comparative analysis to arrive at findings for the interview themes. The metamatrix for the interactive synthesis by To (2010) was adapted in the present study for the qualitative data analysis of semi-structured interviews as illustrated in Table 1 below. 
Table 1. The metamatrix for qualitative data analysis of interviews with BA graduates and employers

\begin{tabular}{c|cccc}
\hline Themes & $\begin{array}{c}\text { Common } \\
\text { positions of new } \\
\text { BA graduate(s) }\end{array}$ & $\begin{array}{c}\text { Satisfaction with new } \\
\text { BA graduates' EOC } \\
\text { performance }\end{array}$ & $\begin{array}{c}\text { New BA } \\
\text { graduates' } \\
\text { EOC difficulties }\end{array}$ & $\begin{array}{c}\text { Key EOC performance } \\
\text { areas for new BA } \\
\text { graduates }\end{array}$ \\
\hline Graduate 1 & & & \\
\hline Graduate 2 & & & \\
\hline Graduate ... & & & \\
\hline Graduate 8 & & \\
\hline Employer 1 & & & \\
\hline Employer 2 & & \\
\hline Employer ... & & \\
\hline Employer 15 &
\end{tabular}

The interview recordings were transcribed. All the answers of the interviewees were analyzed by categorizing the points that came out from the statements for each question. The metamatrix was used as a starting frame of reference for data analysis in the study. Key words and phrases extracted from the interviews were then inserted in the corresponding cells for comparative analysis and eventually, the generation of findings of the above themes with quotes. The quotes were translated into English for the purpose of report and revised by another English teacher who was also a professional translator of six-year experience. The major themes of the interview data including the satisfaction towards BA graduates' EOC competencies, their difficulties in using EOC in the workplace and suggestions from workplace perspectives were analyzed as listed in Table 1.

\section{Findings}

All the results of the interviews were summarized in the metamatrix that was designed based on interactive synthesis. Common positions of new BA graduates, satisfaction towards current BA graduates' EOC competencies, and suggestions for necessary EOC competencies at workplace will be reported in this part.

\section{Common positions of new BA graduates}

At first, the participants were asked about the common positions of BA graduates after being employed and the key EOC performance areas for them to work effectively at the workplace.

Table 2. New BA graduates' common positions

\begin{tabular}{cccc}
\hline No. & Graduates' position after graduation & Yes & No \\
& & $\mathbf{( \% )}$ & $\mathbf{( \% )}$ \\
\hline 1. & Sales personnel & 69.57 & 30.43 \\
\hline 2. & Manager assistant & 39.13 & 60.87 \\
\hline 3. & Import-export personnel & 34.78 & 65.22 \\
\hline 4. & Officer & 30.43 & 69.57 \\
\hline 5. & Human resource personnel & 21.74 & 78.26 \\
\hline 6. & Sales administrator & 13.04 & 86.96 \\
\hline 7. & Market researcher & 13.04 & 86.96 \\
\hline 8. & Manager & 4.35 & 95.65 \\
\hline
\end{tabular}

Results from the interview data about new BA graduates' common positions with 23 employers and BA graduates from workplace were summarized in Table 2. As can be seen from Table 2, the majority of employers and BA graduates reported that BA graduates often worked as sales personnel $(69.57 \%$ for Yes) after being employed. 
Current BA graduates' EOC competencies: Satisfaction level and difficulties

All the examined employers and BA graduates were interviewed in NA about their satisfaction with BA graduates' EOC competencies that included knowledge, skills and attitude/behavior in implementing EOC duties. The qualitative results showed that most of employers and BA graduates (73.91\%) were slightly dissatisfied or dissatisfied with BA graduates' EOC competencies in workplace right after their graduation. BA graduates' weakness in EOC competencies were reported to be various such as their lack of "language structures", "correct pronunciation", "abilities of listening to different accents such as English by Singaporean, Malaysian, Indian, Japanese and French", "tactfulness and strategies in socializing situation", "flexibility" in handling BE situations, and understanding of "communication culture" at work. Specifically, they commented:

"I have the feeling that they [i.e. BA graduates] were just prepared in terms of theory and lacked practice. Many of them were not quick at interaction in English especially at the beginning." (E4)

"I have failed many graduates of BA or any other business majors despite of their degree of high-distinction or even degree from abroad because they had weak communication skills." (E5)

"For sales positions, for example, sometimes customers both foreigners or Vietnamese are willing to work with our employees just because of small things, like their attitude in communicating. But when my employees just acted as if they were higher than the customers, the customers rejected cooperating or required a replacement of sales personnel". (E10)

BA graduates also revealed they were not ready due to lack of EOC competencies when entering the market:

"When I started working for my current company, I was so scared of facing my foreign boss. I could barely understand what she said or asked for. She spoke so fast in strong Indian accent. So I tried to avoid her or even took a day off when she came to Vietnam." (Grad 1)

"I was not prepared for communicating orally with foreign customers. I had to make a lot of effort because my pronunciation was not good enough. There were many errors. I did not have much knowledge about cultures." (Grad 5)

"I was not confident with my EOC abilities after graduation at all. I was almost like a deaf person at first. It took me almost half a year to improve my abilities in listening and speaking English to foreign customers." (Grad 6)

Many of BA graduates (62.5\%) explained that the low level of their self-assessment of satisfaction resulted from the fact that they did not have chance of practice making conversation in English or an EOC course specifically for BA majors. They reported:

\begin{abstract}
"The GE courses were very general with everyday topics like sports, hobbies, and food without focus on speaking. But the ESP course only focused on reading and grammar. So in fact, we did not have an EOC course." (Grad 2)
\end{abstract}

"We studied speaking skills, but only in making a presentation. We did not have chances of making conversations in English with others. I did not have much time to speak or interact in English with peers. I had very few chances of getting correction or feedback from teachers. So after graduation, I was still weak at interaction." (Grad 3)

Besides the BA graduates' weakness in EOC, two employers gave positive comments on their employees as BA graduates in undertaking EOC responsibilities. However, they also explained their situations that:

"However, at first, they (i.e. BA graduates) could not perform as well as required due to their lack of confidence and EOC jargons. Then after some weeks of observing and learning from senior 
colleagues, they started getting better." (E1)

"Those were the best ones that my company selected from series of interviews. In fact, many of other BA candidates failed to meet the company requirements. Most of those who did not pass the interviews had bad pronunciation or very slow response in English." (E3)

In short, the results revealed that most of the BA graduates lacked good pronunciation, skills and appropriate attitudes rather than knowledge in dealing with EOC tasks and much of the dissatisfaction of both employers and BA graduates came from the discrepancies between the university preparation and workplace requirements. It seemed that their weak points in EOC prevented them from working effectively after graduation in EOC situations and resulted from the lack of practice at university in this area of English.

\section{Suggestions for necessary EOC competencies at workplace}

Giving detailed description of the importance of socializing in English for BA graduates, 5 out of 23 workplace participants (21.74\%) claimed that socializing competencies are necessary for those "from new graduates to those with years of working experience". Here are typical emphases by employers:

"Socializing is a very important speaking duty. All employees including BA personnel in our company have to socialize well with foreign clients." (E1)

"I think their main duty is socializing in English. They have to welcome and to build up relationship with foreign clients when they come to visit our company. So when interviewing BA graduates for the job, we only select those with good socializing skills." (E7)

"In terms of speaking, socializing is very important for any positions. From new to experienced graduates or from staff to managerial level, it is a must for them to socialize well in English with foreign business partners." (E12)

Answering about the importance of telephoning performance area, $6 \mathrm{BA}$ graduates and employers $(26.09 \%)$ gave the same reason that many of their foreign clients were working abroad so making a phone call is "the most convenient oral communication way". Employer 13 explained the importance of telephoning as below.

"Making a call is the fastest way to communicate when we cannot have face-toface conversation with our business partners or colleagues."

Besides, 5 participants $(21.74 \%)$ claimed that telephoning was the most frequently used speaking task in travel agencies where they have a great number of tourists from abroad. Graduate 8 working for a travel agency emphasized that:

"Telephoning is definitely the most common English duty that I have done so far. I think it is very important for all of other BA graduates who also work in a travel agency like me."

In terms of the most significant EOC performance areas for new BA graduates, almost all of the participants $(91.43 \%$ and $74.29 \%$ ) affirmed that the competencies in socializing and telephoning should be included in the proposed course respectively. The participants gave comments on socializing:

"Socializing competencies are necessary for them (i.e. BA undergraduates) no matter what position or company they are going to work for in business sector." (E7)

"These competencies (i.e. socializing) are what BA graduates need to use right in interviews for job application so definitely they should be included in the course." (Grad 8)

Graduate 5 reported about taking part in meeting in English that:

"We rarely have formal meetings in English. We mostly have conversations of exchanging information." 
Employer 3 gave comment about presenting duties:

"Giving presentation is not a common duty in our company, only twice or three times per year. And normally, a team leader, manager or deputy manager will be in charge of this."

Graduate 4 explained for not selecting negotiating:

"Compared to other competencies, only a few BA undergraduates may use negotiating in English for their job. Only those who have experiences and higher positions like managers will use it."

In short, two EOC performance areas considered the most important with high percentage of participants ( $>50 \%$ ) for BA undergraduates were socializing and telephoning competencies.

\section{Discussion}

It can be illustrated from the findings of the semi-structured interviews that employers were those who could probably know well the strengths and weakness of their employees who graduated from universities in meeting the requirements of real workplace. Besides, graduates who experienced both learning needs and communication needs could give insightful report on the possible discrepancies between the academic preparation and real workplace. Nevertheless, ESP teachers are likely to be the only ones to be in charge of designing and implementing ESP courses as reported by Huhta et al. (2013). They stated that much of the development of Language for Specific Purposes and study skills courses had been largely based on the teachers' intuition, rather than any rigorous investigation of what actually happened. Consequently, if teachers just follow a book, it will probably cause enormous discrepancies because every book or material has its own weakness and strengths. Besides, a book that was published in a different context or a foreign country such as London and New York could hardly take into consideration all of Vietnamese learners' common mistakes or needs; or the specified socio-cultural requirements of Vietnamese workplace. The shortage of a needs analysis of the workplace could hardly make a course context-based because it was not designed from the findings of needs by all the relevant stakeholders in the studied context. This issue eventually can lead to the considerable discrepancies between university preparation and workplace requirements.

Besides, based on the qualitative results, transferable skills such as "tactfulness and strategies in socializing situation", "flexibility" in handling BE situations besides language competencies and also understanding of "communication culture" at work are several BA graduates' weaknesses in EOC, which resulted in their employers' dissatisfaction with their EOC performance in workplace. Therefore, in order to help BA undergraduates to get ready to meet all the workplace requirements, a competencybased course can be a feasible solution with comprehensive focus on development of knowledge, skills and attitudes as a thorough preparation for workplace. Norton (1987, as cited in Sullivan, 1995) states that learners' confidence is enhanced in competencybased education because they can achieve competencies required in the performance in real life. However, the necessity of effective teachers in a competency-based classroom, which requires teachers' adequate qualification and training in competency-based language teaching can be an issue. Sullivan (1995) claims that unless training and follow up assistance is provided for the teachers, there is a tendency to slip back into the role of the traditional teacher. Therefore, teachers must be active in classroom with the commonality of completing the same training, which means preparing them ready for teaching the proposed course is essential. 


\section{Conclusion}

This article has reported the investigation with workplace representatives including BA graduates and their employers. The findings reveal that most of employers were slightly dissatisfied or dissatisfied with the new graduates' EOC competencies. This emphasizes the importance of an investigation of real workplace requirements and reflection. Therefore, one implication is creating longterm collaborative partnerships among and between potential employers, teacher educators, and teachers and in designing an effective EOC course for BA undergraduates to get them ready for the workplace. Besides, the competency-based approach as the basis for the design of work-related and survivaloriented language teaching programs for adults (Richards, 2006) can be applied in response to the growing concerns that students were not being taught what they required after they left school. Regarding room for further research, the scope of study can be widened with more BA graduates from more universities that have ESP course(s) for BA undergraduates would better guarantee the validity of the research.

\section{Acknowledgements}

First and foremost, I would like to express my sincere appreciation and gratitude to Assoc. Prof. Dr. Nguyen Phuong Nga and Dr. To Thi Thu Huong for their extensive expertise and professional advice. They have been such a great source of inspiration and support for me to conduct this research.

I would like to acknowledge a particular debt to employers and business administration graduates who have taken part in this study and spent time answering my interview questions. The information collected was a precious source of data to make the research fruitful. Importantly, their enthusiastic participation and support with professionalism have been great encouragement for me to complete the research.

\section{References}

Chien, C., Lee, W., \& Kao L. (2008). Collaborative teaching in an ESP program. Asian EFL Journal, 10(4), 114-133.

Council of Europe, (2001). The Common European Framework of Reference for Languages, Cambridge University Press, 23-193.

Crosling, G., \& Ward, I. (2002). Oral Communication: The Workplace Needs and Uses of Business Graduate Employees, English for Specific Purposes, 21(1), 41-57.

Dayal, S. (2005) English Language Learning in the ESPContext: an Indian Experiment, Language in India, 6(4). Retrieved 15 April 2019 from http://www. languageinindia.com/aug2005/shebaesp1.html

Dibakanaka, A., \& Hiranburana, K. (2012). Developing an e-Learning Competency Based English Course Module for Chief Flight Attendants. International Journal of Scientific and Research Publications, 2(8).

Do, T. P. T. (2012). Vietnamese students' levels of English proficiency: Far from the standard level. Paper presented at the Conference on the Quality of the Teaching and Learning of English in Higher Education in Vietnam, Hanoi, Vietnam.

Dowsett, G. (1986). Interaction in the semi-structured interview. In M. Emery (ed) Qualitative Research. Canberra: Australian Association of Adult Education.

Dudley-Evans, T., \& St. John (1996). Report on Business English: A Review of Research and Published teaching material. Princeton: Chauncey Group International.

Ellis, M., \& Johnson, C. (1994). Teaching Business English. Oxford: Oxford University Press.

Fischer, C., \& Wertz, F. (1975). Empirical phenomenological analyses of being criminally victimized. In A. Giorgi (Ed.), Phenomenology and psychological research. Pittsburgh, PA: Duquesne University Press, 135-158.

Guskey, T.R. (2005). Mapping the road to proficiency. Educational Leadership, 63(3), 32-38.

Hoang, V. V. (2008). Factors influencing the quality ofthe teaching and learning in a non-English major program in the Vietnamese national university, Hanoi. The Journal of Social Science, 8, 22-37.

Huberman, A. M., \& Miles, M. B. (1994). Data management and analysis methods. In Denzin, N. K. \& Lincoln, Y. $\mathrm{S}$. (eds) Handbook of qualitative research. Thousand Oaks : Sage Publications. 428-444.

Huhta, M., Vogt, K., Johnson, E., \& Tulkki, H. (2013). Needs Analysis for Language Course Design. A holistic Approach to ESP. Cambridge: Cambridge University Press.

Hymes, D. (1972). On communicative competency. ed. J B. Pride and Holmes, H. Sociolinguistics. N.Y: Penguin.

Long, M. (2005). Methodological issues in learner needs analysis. Cambridge: Cambridge University.

Pattanapichet, F., \& Chinokul, S. (2009). Development of 
a Competency-based English Oral Communication Course for Undergraduate Public Relations Students. ESP World, 4(25), 1-46.

Richards, J. C. (2006). Communicative Language Teaching today. Cambridge: Cambridge University Press.

Richards, J., \& Rodgers, T. (2001). Approaches and methods in language teaching. Cambridge: Cambridge University Press.

Savignon, S. J. (1983). Communicative competency: Theory and Classroom Practice. Reading, MA: Addison-Wesley.

Sullivan, R. S. (1995). The competency-based approach to training. JHPIEGO Strategy Papers, 1, 1-8.
To, T.T.H. (2010). Insights from Vietnam. In R. Johnstone (Ed.), Learning through English: Policies, Challenges and prospects. Insights from East Asia. Malaysia: British Council.

Tsou, W. (2009). ESP makes college EFL learning effective. Paper accepted for presentation at TESOL 2009 Annual Conference, Denver, CO, 26-28 March.

Vasavakul, A., \& Chinokul, S. (2006). Business English oral communication (BEOC) for customerservices staff at international banks: Translating needs analysis to a course development. (Doctoral Dissertation). Faculty of English as an International Language, Chulalongkorn University.

\title{
GÓC NHÌN TỬ NƠI LÀM VIỆC THỰC TẾ VỀ NĂNG LỰC GIAO TIẾP NÓI TIẾNG ANH CỦA SINH VIÊN TỐT NGHIỆP QUẢN TRI KINH DOANH
}

\author{
Nguyễn Thị Minh Trâm \\ Bộ môn Chất lượng cao, Khoa Su phạm tiếng Anh, Trường Đại học Ngoại ngũu, ĐHQGHN, \\ Phạm Văn Đồng, Cầu Giấy, Hà Nội, Việt Nam
}

Tóm tắt: Sự chênh lệch giữa chương trình tiếng Anh cho sinh viên quản trị kinh doanh (QTKD) và các yêu cầu về năng lực giao tiếp tiếng Anh tại nơi làm việc trở nên đáng báo động kể từ khi Việt Nam gia nhập các tổ chức thương mại quốc tế, đặc biệt là Cộng đồng kinh tế ASEAN. Trong bài nghiên cứu này, dữ liệu định tính được thu thập từ các cuộc phỏng vấn bán cấu trúc với các bên liên quan tại nơi làm việc thực tế, bao gồm 15 nhà tuyển dụng ở cấp điều hành và quản lý và 8 sinh viên tốt nghiệp QTKD từ bốn trường đại học để tìm hiểu sự chênh lệch này. Kết quả cho thấy hầu hết các đối tượng nghiên cứu đều không hài lòng với khả năng nói tiếng Anh tại nơi làm việc của các sinh viên mới tốt nghiệp ngành QTKD. Như vậy, việc tạo ra mối quan hệ hợp tác lâu dài giữa các cơ sở đào tạo và nhà tuyển dụng, và thiết kế khóa học theo đường hướng năng lực là cần thiết nhằm nâng cao năng lực này cho sinh viên QTKD để sẵn sàng thích ứng với yêu cầu thị trường ngày càng khắt khe.

Tù khóa: giao tiếp nói trong tiếng Anh, Quản trị kinh doanh, năng lực 


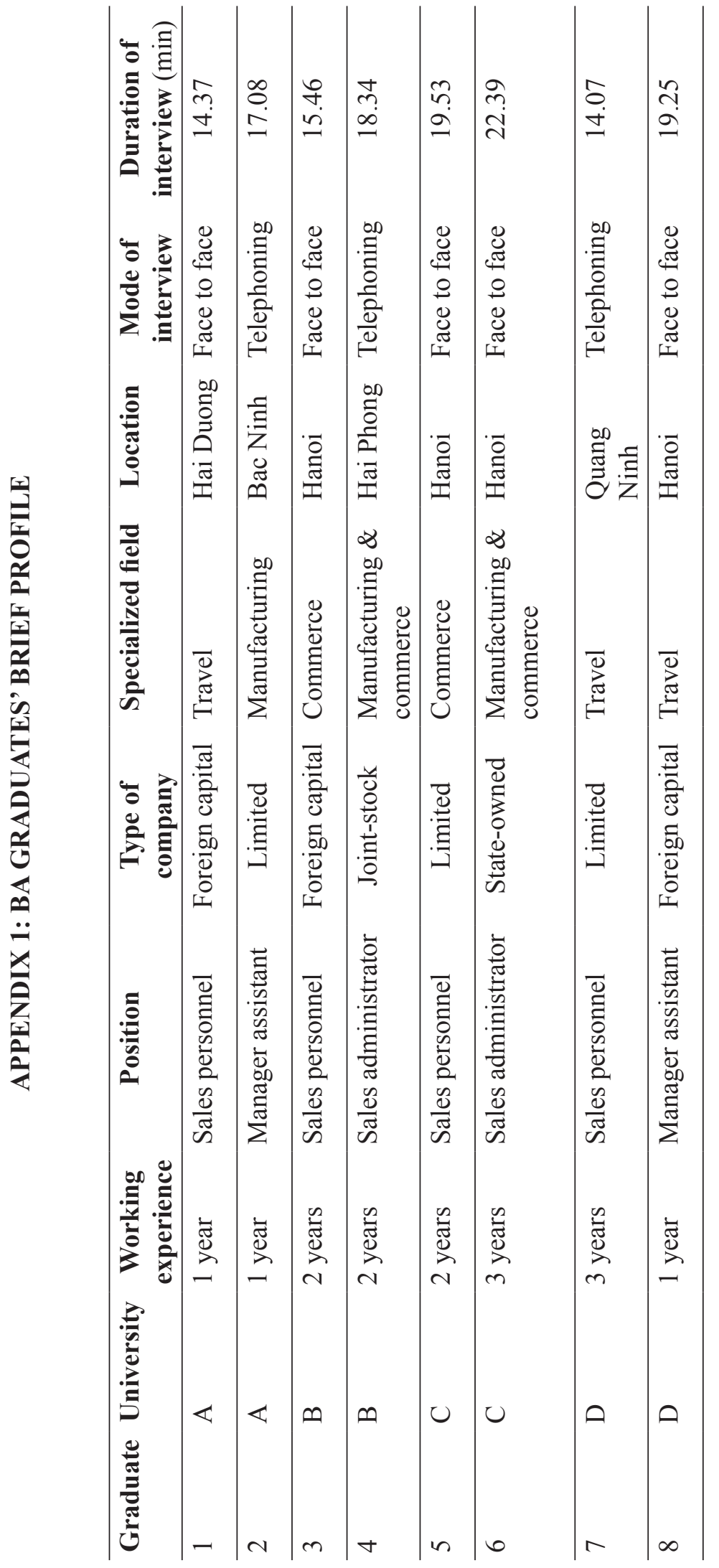




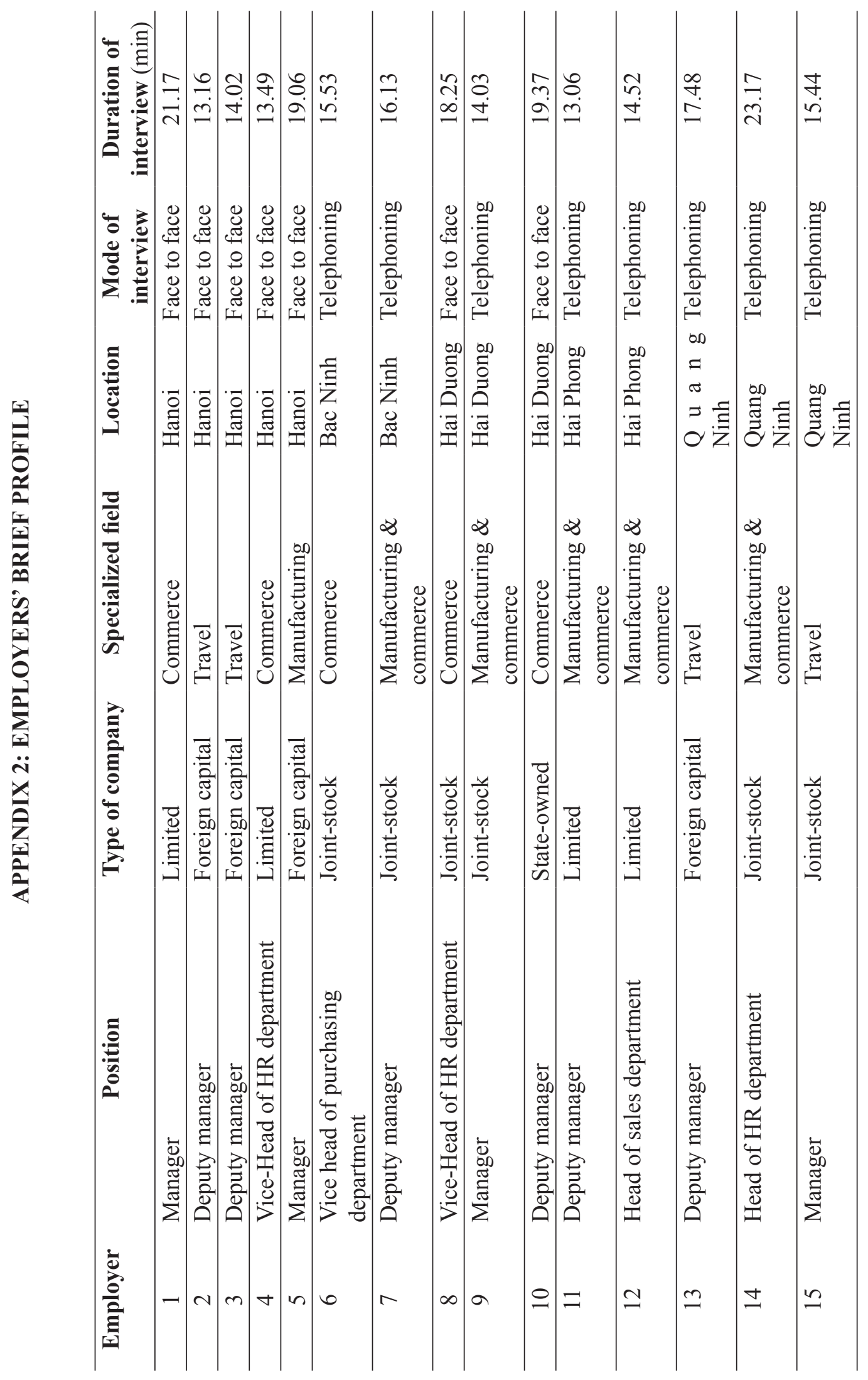

